\title{
PHENOMENOLOGICAL CHARACTERISTICS OF TERRORISM AS A SEVERE FORM OF POLITICAL CRIME
}

\author{
UDC 327.88
}

\section{Borko Milošević}

\author{
Academy for National Security, Belgrade, Republic of Serbia
}

\begin{abstract}
In the last few decades, terrorism, as a severe form of violence, has grown into one of the greatest and almost unsolvable challenges for individual states and the international community alike. The author has tried to contribute to a comprehensive scientific explanation of terrorism as a serious form of crime of violence and its phenomenological characteristics. The author points out that scientific research of the methods, contents, forms and phenomenological characteristics of terrorism may contribute to creating conditions for effective suppression and counteracting of this form of violence. The study of terrorism and its phenomenological characteristics is important because it leads to reaching a consensus on this form of violence and its main features, and in conjunction with the research on terrorism from the ideological, philosophical, ethical and other aspects, it ultimately creates sound grounds to successfully counteract terrorist activities.
\end{abstract}

Key words: terrorism, political violence, safety, causing fear

\section{INTRODUCTION}

In the modern world, many countries are under constant threat of terrorist activities, whose organizers and perpetrators are mainly driven by political, social and religious motives in an effort to achieve their political goals. Terrorism is organized violence, ultimately aimed at destroying the authority of a state and its institutions, or accomplishing some other political goals. In the adverse circumstances preceding a civil war or an interstate armed conflict, terrorism is typically preceded by a crisis situation, radicalism and extremism. Terrorism emerges in conditions of crisis that trigger extremism, which clearly embodies the idea of accomplishing specific political goals by embarking on organized forms of cooperation with intelligence services, terrorist organizations and organized criminal groups.

Received December $27^{\text {th }}, 2016 /$ Accepted June $26^{\text {th }}, 2017$

Corresponding author: Borko Milošević, LL.M

Academy for National Security, Belgrade, Republic of Serbia

E-mail: borkolaw@gmail.com 
The common characteristics of all criminal acts are their illegal nature, social danger, and harm caused to the individual and the society, for which reason they are qualified as negative social phenomena, i.e. crime. There is a large number of criminal offenses which are qualified as crimes of violence, regardless of the object of attack, where violence is either the essential element of the offense or the mode of its commission. All forms of violence are characterized by the perpetrator's aggressive behaviour towards the victim. In the context of commission of criminal offenses involving the use of violence for the purpose of achieving political goals, there is a special kind of a violent crime which is designated as political crime. Political crime is closely associated with political relations in a society, and it includes two groups of criminal offences. The first group comprises criminal acts against the state (perceived as the governing authority), such as: treason, espionage, armed insurgency, terrorism); the second group consists of crimes committed by the government against political opponents and crimes committed for the purpose of unlawful enrichment.

\section{DEFINITION OF TERRORISM}

\subsection{The concept of terrorism}

Today, terrorism is one of the most frequently discussed political topics. There is no part of the planet which has not encountered this phenomenon. While classical wars and armed conflicts prominent in the 20th century are now generally considered to be part of history, in the late $20^{\text {th }}$ and early $21^{\text {st }}$ century individual states and the international community were confronted with the growing phenomenon of political violence which has replaced wars as we know them from history books. Diverse forms of political violence are an interesting topic for scientists who endeavour to tackle the definition of terrorism. In order to know what we are fighting against and how to fight against it, we first have to know what it is (Simeunović, 2009: 6).

Defining terrorism is by no means an easy task, primarily considering the vast number of diverse forms of this crime. Terrorism is variable and dynamic because it is conditioned by numerous factors. Administrations of some countries have double standards in terms of terrorism, which is either improperly and incomprehensively defined or completely disregarded as a phenomenon, primarily because they have some political interest from the emergence of terrorism in "another's backyard". Yet, it is necessary to make a clear distinction between terrorism and related emerging forms of political violence. Terrorism is the systematic, random and targeted violence against the same target which is not necessarily caused by their guilt, but is purely a reflection of one's free choice, great situational superiority and will to be violent (Simeunović, 2009: 23). Terror is an intense form of violence carried out by someone who is in dominant position, which does not only imply the position of power but also the use of all currently superior positions in human relations. Terror carried out by the government authorities always implies lawful violence, i.e. a legitimate use of force (Simeunović, 2009: 25). Guerilla can be defined as a form of combat-organized political activity of small, armed and highly mobile illegal groups which, under the guise of representing the interests of the people, resort to collective use of armed force as direct violence against the occupiers (Simeunović, 2009: 28).

In view of the prominent attempts to define the concept of terrorism, there is an obvious need to create a comprehensive and widely accepted definition (Simeunović, 2005: 100). 
Vojin Dimitrijević argues that every act of terrorism is a political act because it is determined by the relationship between the perpetrator and the authority (Dimitrijević, 1982: 37). Prof. Dragan Simeunović, one of the best Serbian theorists on terrorism, thinks that the phenomenon of "modern terrorism" may be theoretically defined as a complex form of organized, individual and less frequently institutional political violence, marked by daunting methods of political struggle aimed at accomplishing "the great goals" in a manner which is inappropriate in the specific circumstances, primarily the given social situation and historical possibilities of those who use it as a political strategy (Jovašević, Rakić, 2007: 59). The definition of terrorism may be subject to further discussion but it is indisputable that terrorism uses violence as a method, fear as a means, state power as a target (not necessarily the object of attack), and political and social change as a goal. The main reasons why it is difficult to define terrorism are political rather than theoretical. Namely, many authors and institutions approach the challenge of defining terrorism with strong conflicting interests which are ultimately aimed at resolving other political and geostrategic issues. Being well-aware of the activities of terrorist organizations and groups, which they may covertly support or whose activities go hand in hand with their own interests, they commonly qualify terrorism as a moral wrong.

\subsubsection{Characteristics of terrorism as a serious form of political crime}

In observing terrorism as a phenomenon and a severe form of political crime, our starting point is that terrorism is strictly a political phenomenon. Terrorism never occurs without political connotations, which are either a cause or a consequence thereof. In other words, terrorist activities always have political implications, entailing either the fight against a center of political power or an endeavour to create their own. Notably, terrorism is a systematic use of violence for the purpose of proclaiming political values and forcing the state authorities to meet the terrorists' demands. The systematic use of violence implies a planned, deliberate and organized activity aimed at achieving the envisaged goals.

The phenomenon of terrorism is manifested in several ways. Apart from the use of violence, terrorism is characterized by mental manipulation and indoctrination. Depending on the short-term goals of terrorist organisations, the message which is sent by the commission of a terrorist act may vary but, generally speaking and in the long run, it symbolizes the ultimate motive and determination of terrorists in their attack on the state. The message is even more prominent due to the importance of the targeted object to the holders of state power. In order to achieve various goals, terrorist may target both individuals and property. Under the typology provided by C.J.M. Drake, the types of targets are distinguished according to the purpose of attacks. This typology includes four types of targets: symbolic, functional, logistic and affective. The attack on symbolic targets is aimed at producing a strong "echo effect" and causing psychological reactions of the general public (fear, frustration, panic). Functional targets are objects that represent a threat to the organization that carries out the terrorist activity. Logistic targets are struck for the purpose of protecting or providing logistic support to a terrorist organization. Affective targets are an expression of an emotional response rather than a planned strategy.

The attempts to find a universal definition of terrorism and the analysis of its phenomenological characteristics have taken us to the field of political violence, where we necessarily have to examine the terrorists' goals and objectives as a very important factor in the assessment of terrorism as a form of violence. In this context, we can observe several distinctive characteristics of terrorism: 
- extremist causes: reflecting highly diverse ideological orientations of terrorist organizations and their capacity to take part in armed conflicts or to act independently, which significantly precludes attempts to identify and qualify the committed terrorist act;

- terrorism as an act of communication: the terrorist activities committed in the past were unable to produce social change but they are considered to have been symbolic actions because they sent the message to the public about the presence and objectives of a terrorist organization, and implied prospective commission of similar acts of violence;

- terrorism as an act of intimidation: in addition to the aforesaid relations between the terrorists, victims and goals/objectives, it is important to draw attention to the pattern emerging alongside the committed act of terrorism, which includes the crucial role of mass media and huge publicity given to the terrorist act and organisation; in that context, insufficient knowledge about the organization, planning and scale of terrorist actions generates a strong sense of insecurity in the general public and, thus, the psychological effects of the committed terrorist act often exceed its physical consequences;

- terrorism as an amoral act: considering that a terrorist act is declared to be an attack on the established system of values, terrorism can be seen as an anti-moral or amoral act which "casts doubt on our conception of law in a society and the obligations of a state" (Horowitz, 1977: 283-297);

- terrorisms as an illegal act: irrespective of the ultimate aim pursued, a terrorist activity must necessarily be examined from the aspect of positive law, under which the commission of an act of terrorism is a legally prohibited criminal act, which calls into question the need for a legal definition of terrorism;

- an element of surprise: it is a prominent feature of terrorist activities in terms of place, manner and time of committing the act, which is accomplished by applying the principle of conspiracy, both in the preparation and in the implementation stage;

- determination: the commission of terrorist activities is invariably driven by strong resolve and fanatic urge to persist in the endeavour at all costs;

- arrogance: this feature implies the impertinence/impudence/insolence presumptuous audacity to strike in places where a victim or the target feels safest;

- offensive nature of terrorist activities: the constant use of violence and commission of terrorist activities are aimed at causing fear and panic in the victim and/or general public, and sending the message that the attack is possible at any place and at any time);

- artifice: it implies the ability to organize terrorist activities in such a way that the national security authorities are provided with misleading information and driven to wrong conclusions, which makes them weak and puts them in an inferior position);

- mobility: this feature implies the ability to change locations and vehicles, to cover trails, to impart wrong information or deceive (etc.), which enables terrorists to keep their activities unnoticed, difficult to trace and, eventually, precludes a timely response of the state aimed at preventing the commission of terrorist acts;

- coordination of activities of terrorist groups: this feature largely depends on the mutual ties, cooperation and integrity of organizations, groups and individuals) ${ }^{1}$.

\footnotetext{
${ }^{1}$ There are soft and strong relations between terrorist groups. Soft relations are characterized by solidarity with the cause or actions of another terrorist organization, relations between various terrorist organizations with
} 
Contemporary terrorist organizations have a clear idea who they are fighting against; thus, prior to commission of terrorist acts, terrorists directly or indirectly "get to know" the target of attacks (Jovašević, Rakić, 2007: 75). One of the important distinctions between terrorist organizations in the past and contemporary terrorist organizations is that the latter are nowadays better equipped with quality agents, weapons and laboratories, and their training in terms of organization and operations is much more sophisticated than it used to be in the past; it is a commonly known fact that some terrorists were trained in military camps by various security services and eminent experts. In some cases, terrorism is also characterized by strong ties with organized criminal groups and organized crime in general. This relationship exists when a terrorist organization establishes a link with the representatives of the ruling political structures in the country and embarks on criminal activities leading to the emergence of organized crime. The most common illegal activities are drug trafficking and trafficking in weapons, which bring huge profits; these financial resources are subsequently used for financing terrorist activities.

One of the most important features accompanying all acts of terrorism is extensive media coverage, which is one of the planned goals of terrorist activities. Through media coverage of their terrorist activities, a terrorist organization communicates with the population. The terrorists' unilateral declaration that some terrorist activities are significant because of their "liberation character" increases the vulnerability of the global community (Jevtović, 2012: 48) ${ }^{2}$. In this sense, we can say that the media coverage actually empowers the terrorist organizations, without which they would be marginalized and their activities would often be unnoticed. As most terrorist acts involve the use of bombs and explosive devices, such attacks are invariably covered by the media. Thus, reporting on terrorist attacks meets the terrorists' objectives in terms of spreading fear and panic among the general public, but it is also interesting that media frequently fail to label the perpetrators' activities as terrorism. It is likely that these attacks will make us think of them as a cruel and unbearable event but, in some places, some of us will think that this is a legitimate struggle for freedom (Whittaker, 2002: 128-133).

\section{CRIMINOLOGICAL CHARACTERISTICS OF TERRORISM}

\subsection{Forms of terrorism and its characteristics}

Based on the motives, terrorism is defined as a form of political crime and "violence aimed at achieving political goals" (Konstatinović-Vilić, Nikolić-Ristanović, Kostić, 2012: 167). At the global level, achieving political goals through violence constructs a new type of a war without grounds and battlefields, where the enemy is without a name and profile (Šikman, 2007: 177). Due to global changes, there is a constant change in the forms of

similar ideology, and overall strategy of terrorist organizations based on or influenced by another organization strategy. Strong links are characterized by making alliances and issuing joint announcements or statements, using the same methods and tactics selected and used under the influence of other organizations, providing necessary logistics and procurement (besides weapons and finance) for another terrorist organization, joint attacks and operations involving participation of a number of terrorist organizations, actions carried out in the name of other organizations, joint training or training by other organizations, providing protection and safe houses for other organizations, groups or individuals, distributing weapons to be used by the same terrorist organizations, financing another organization, etc.

2 Jevtović ( 2012: 48), cited after Konstatinović -Vilić, Nikolić-Ristanović, Kostić (2012). 
terrorism which entail new features. Thus, Alen de Benoist ${ }^{3}$ founded of a theory that terrorism is "an act of war". He believes that terrorist organizations are decentralized and without a clear hierarchy in terms of structural organization; thus, the network does not cease to exist or weaken by eliminating the leader of the organization, but preserves its fractional structure and interpersonal relations.

On the other hand, authors like Richard Falk ${ }^{4}$ consider terrorism as a universal phenomenon of a worldwide impact, whereby all its changes may be attributed to the current trends in the development of the US administration foreign policy. Falk designates this modern terrorism as mega-terrorism, which differs from earlier forms of terrorism by its scope, power and ideology. He specifies the most important features of mega-terrorism (Šikman, 2007: 178):

- substantive and symbolic damage: the scope of attack indicates a high level of determination, intent and capacity but, notwithstanding the amount of damage and the loss of thousands of lives, terrorist acts are performed against symbolic targets, jeopardizes the fundamental concept of security;

- genocidal intent: individuals or groups are targeted as objects of attack solely because of their ethnic, religious and national origin;

- visionary goals: terrorist organizations are often driven by goals of visionary nature, such as the creation of a single Islamic state;

- tactical ingenuity: the level of organizational and operational capacities of terrorist organizations is high and their activities are a result of good training and technical knowledge, projecting an image of being well-organized and disciplined organizations;

- unconditional motivation: absolute motivation and resolve of organization members;

- a resounding message: a completed terrorist action enjoys a huge media coverage and sends a clear reverberating message to the authorities and the general public;

- a security crisis: the committed act of terrorism implies a direct threat to safety.

Together with the development of society, modern terrorism is constantly changing its shape and characteristics to such an extent that each subsequent form bears almost no resemblance with the previous one. This makes the fight against terrorism even more difficult and complex. There is a growing number of terrorist actions aimed at causing death of a large number of people and incurring substantial material damage; the targets are increasingly more diverse and the objectives are progressively more radical. In order to cause more substantial devastation, terrorist organizations are trying to come into possession of weapons of mass destruction. In this regard, there is a growing correlation between organized crime and terrorism (Milašinović, Mijalković, 2001: 1-16).

There are diverse forms of terrorism, depending on the elements taken into consideration. Thus, according to the geographical territory where terrorist actions are prepared and carried out, terrorism can be divided into: internal terrorism and terrorism of international importance (including: transnational terrorism which implies actions of non-state actors and interstate terrorism which is performed by states). Considering the choice of the

\footnotetext{
${ }^{3}$ Alen de Benoist (born on 11 December 1943) is a French academician and philosopher, the founder of the school of political thought "New Right-wing" and head of the French research institute (think-tank) GRECE. He is a critic of neoliberalism, free markets, democracy and egalitarianism.

${ }^{4}$ Richard Anderson Falk (born on 13 November 1930) is an American professor emeritus of international law at Princeton University. In 2008, the UN Human Rights Council (UNHRC) appointed Falk (for a six-year term) as a United Nations Special Rapporteur on the situation of human rights in Palestinian territories occupied since 1967.
} 
target, terrorism may be selective, non-selective and target-specific; according to the target size, it may be individual and group terrorism. Taking into account the terrorists' personal involvement in the activity, it may be direct and ordered (mercenary). According to the geographical space of action, it may be urban and rural. Considering the relations between the participants in a terrorist action, it may have the following forms: a state against another state, a state against a non-state entity, a non-state entity against a state, and a non-state entity against another non-state entity. Considering the prominent motifs, it may be designated as nationalist, separatist, religious, subversive and emigration-related terrorism. According to political orientation, it may be reactionary and revolutionary. Yet, considering the main objectives to be achieved, terrorism can be divided into three groups:

- ideologically motivated terrorism: a major problem in defining terrorism is to determine whether an act of terrorism has been fueled by ideology, or is merely an act of violence;

- ethno-separatist terrorism: an important feature in this type of terrorism is the separation of an ethnos from a recognized politically organized state, establishing a separate state or obtaining autonomy with prerogatives of a state (Simeunović, 2009: 83);

- religion-driven terrorism: there is a propensity of considering Islam to be the generator of political violence but the causes of Islamic terrorism certainly cannot be sought only in the sphere of religion; namely, in this form of terrorisms, Islam (or religion in general) is used as a source, an excuse and an instrument for exerting terror and violence against "non-believers" by a number of fanatic believers/members of terrorist organizations.

\subsubsection{Conventional terrorism}

Conventional terrorism is subdivided into distance terrorism and suicide terrorism.

Distance terrorism appeared at the beginning of the $20^{\text {th }}$ century. Its main feature is attack from a greater or lesser distance, usually by using explosive devices which guarantee a political and propaganda effect, and less frequently by using firearms (sniper fire, closerange shooting, random gunfire and riots). Terrorist actions can be performed by using cold weapons as well, but this method requires a minimum distance between the object and the perpetrator, which is usually the most serious problem in terrorist actions. Terrorists also opt for toxic substances, and often take hostages as a means of fighting for their cause.

Suicide terrorism is a very specific form of terrorism due to the mode of implementation. This form of terrorism is very difficult to counteract because of the absolute determination of terrorists to sacrifice their own lives for a political goal, while the suicide attack is precisely planned and logistically supported by a well-organized terrorist organization. Suicide terrorism is the most aggressive form of terrorism and it includes a certain form of coercion, aimed at inflicting enough pain to the victim, cause general panic and punish the wider environment (Pape, 2003: 343-361). The main feature of this type of terrorism is a deliberate decision of fanatic terrorists to sacrifice their lives for the cause of the terrorist organization, whose activities are generally perceived as immoral, cruel and covert. It has given rise to a new form of suicidal terrorism, which gave terrorists the edge of ruthless extremists. Namely, apart from having lethal weapons at their disposal, terrorists have the power to die on their own terms. Thus, they use both weapons simultaneously. The old suicidal terrorism was the terrorism of the poor, and this new one is the terrorism of the rich (Baudrillard, 2007: 211-221). 


\subsubsection{Unconventional terrorism}

This form of terrorism is characterized by the absence of armed attacks, which makes it difficult to recognize by the state protection systems. Unconventional terrorism implies the use of psychological-propaganda activities, misuse of information by means of mass media (radio, television, press and information systems), causing fear by making terrorist threats, inciting rebellion in state institutions with political motives, etc.; the ultimate aim is to draw attention of the international community to the political goals of some terrorist organizations and gain support of the most influential and wealthy countries in the world for their cause (Gaćinović, 2012: 7). In this context, it can be concluded that the nonconventional terrorism occurs before the conventional terrorism as a preparatory stage for using armed attacks and commission of terrorist actions. For these reasons, this kind of terrorism is also called covert terrorism because the actions are carried out by specialized units using "someone else's hands", whereas the act of assuming responsibility for specific actions by a terrorist organization is no more than an attempt to conceal the real goals and interests of the principals.

\subsubsection{Environmental terrorism}

Environmental terrorism is destruction or a threat to destroy the environment and the people, plants and animals. At the beginning of the $21^{\text {st }}$ century, environmental terrorism became perhaps the greatest danger to the world as we know it today. If the commission of terrorist acts involves the use of mass destruction weapons, we can differentiate three types of eco-terrorism:

a) nuclear terrorism, which involves the use of nuclear weapons in the commission of terrorist actions; until recently, it has been accessible only to a few countries which had the funds and capacities but, with the collapse of the Soviet Union and the emergence of a number of independent and autonomous individual states, there has been a significant increase in trafficking large quantities of nuclear materials and mercury on the black market; this has generated ideal conditions for the production of weapons for mass destruction as well as the opportunity for terrorist organizations to come into possession of such weapons;

b) chemical terrorism, which poses a real danger because of the simplicity of procuring chemical weapons if a terrorist organization decides to use this type of terrorism; chemical terrorism may result in mass starvation of people and/or causing huge economic damage; during the perpetration of a terrorist act, the application of chemical agents is covert and difficult to detect, in which case we can talk about the "covert impact of undercover terrorism," where the real causes of destruction are difficult to trace);

c) biologic terrorism, which implies terrorist activities carried out by means of biological materials (biological agents, toxins, viruses, bacteria, fungi, etc.) with the aim of causing disease of civilians or armed forces; they are commonly used in densely populated areas for the purpose of causing a huge number of casualties and destroying the morale.

The common name for these three types of terrorism is super-terrorism, or postindustrial terrorism, whose consequences are immeasurable in terms of the number of casualties and material damage. 


\subsubsection{Cyber terrorism}

Postmodern (high-tech) terrorism involves the abuse of modern technologies in carrying out terrorist activities. Cyber terrorism is a special aspect of this form of terrorism which implies politically motivated attacks by national groups, undercover agents or individuals against the information and computer systems, computer programs and data. It is "an unauthorized attack or threat of attacks against computers, computer networks or stored data in order to frighten a government and its citizens in order to achieve political or other goals". 5 As such, it ultimately leads to violence against civilian targets.

\subsubsection{Narco-terrorism}

From the aspect of its goals, terrorism can be observed as violence carried out for accomplishing political goals and criminal-political goals (Memedović, 2010: 96). As a form of political violence, terrorism mainly entails politically motivated killings and assassinations. Terrorism as a form of violence motivated by criminal and political causes is carried out by organized criminal groups, which are primarily interested in enrichment, i.e. maintaining or increasing their wealth by attaining illicit profit. Nowadays, organized crime and terrorism are the largest non-military transnational security threats, especially given the close cooperation between the perpetrators of these criminal acts. There are numerous examples of terrorists being involved in organized crime, and organized criminal groups frequently use the methods of terrorist organizations. Thus, terrorism may be designated as a form of organized crime but the relationship between these two phenomena can be discussed only in terms of the level of their correlation, primarily because organized crime is part of property-related crime and lacks the ideological and political motive which is inherent to terrorism. The correlation of organized crime and terrorism is usually functional, given that organized crime often serves as a means for financing terrorism; the connection can also be instrumental, when terrorist organizations get involved in organized crime and, vice versa, when organized criminal groups undertake terrorist actions (Mijalković, 2008: 42). In that context, narco-terrorism implies activities aimed at financing terrorist organizations and campaigns by money acquired through unauthorized production and trade of narcotics. These activities are organized and carried out by narco-cartels which apply terrorist methods in order to gain political power and legitimacy for their causes.

\section{CONTEMPORARY FORMS OF TERRORISM}

In international relations, there are two prominent forms of modern terrorism: transnational terrorism and interstate terrorism.

Transnational terrorism implies the use of violence or a threat to use violence for the purpose of achieving political goals whose consequences transcend national borders. Transnational terrorism includes all forms of terrorism in international relations whose perpetrators are non-state actors. In these terrorist actions, there is cooperation between terrorists from several countries, based on the convictions of terrorist organizations members. This kind of terrorism entails violent methods of combat against the home state;

\footnotetext{
${ }^{5}$ Cyber Terrorism, Wikipedia - the free encyclopedia, available at: http://sr.wikipedia.org/sr-ec/Sajber_terorizam, (Accessed 09/13/2016)
} 
terrorist usually come from several foreign countries, without the knowledge of their governments. This non-state terrorism is commonly motivated by the terrorists' separatist and national aspirations to secede a territory predominantly inhabited by one ethnic group.

Interstate terrorism exists when the authorities of a state organize and carry out terrorist acts against another state or a number of states (Gaćinović, 2005: 261). Terrorist actions against another state may be performed either covertly or publicly. This form of modern terrorism is carried out in order to destabilize the public order in another country-the victim of violence. Foreign states are associated with terrorist organizations in the victimstate, and take actions governed by the principle "our interest, someone else's hands". These networking activities with members of terrorist organizations are mainly entrusted to the intelligence services. Unlike transnational terrorism, interstate terrorism is a tool of the state. One of the main characteristics of this form of terrorism is the hypocrisy of a state that covertly undertakes activities in the victim-state ("by its own or someone else's hands") in greatest secrecy, whereas publicly advocating the internationally recognized principles on combating terrorism. Their hypocrisy is also reflected in cases where it is impossible to deny their own involvement in a terrorist campaign, considering the public declarations that it is a legitimate act of warfare.

\section{CONCLUSION}

There is no dispute that terrorism as a social phenomenon has become part of our everyday life. If not directly, we encounter many forms of terrorism through the media. The extraordinary ability of terrorism to change the dynamics of its ample forms and adapt to specific circumstances makes it difficult to establish control over this phenomenon and complicates the process of establishing adequate mechanisms for counteracting this criminal activity. In public, there is an increasingly common view that terrorist organizations are coordinated by security structures or special services, which are still under the control of states that have their own agenda, i.e. extreme and highly serious eco-strategic and geopolitical objectives. In line with the principle of "if something happened, someone needed it", it may be concluded that there is no terrorist organization that does not have a special service as a mentor; therefore, there is no terrorist activity which does not involve the goals or interest other countries and their special services. Due to circumventions in defining the causes of terrorism and the failure to normatively frame the actual causes of terrorism, there is an ongoing skillful transformation of terrorism, which is almost never put under full control.

Different historical periods have been marked by different forms of terrorism. In the earliest stages, it was less radical and did not enjoy a huge media coverage while, in the last decades, we bear witness to very brutal acts of violence of terrorist organizations with clearly defined political goals. A change in the terrorists' mindset and their overall indoctrination has not been short-lived; nevertheless, the international community response seems to be constantly lagging behind in terms of providing an adequate anti-terrorist doctrine. In addition to this drawback, it is necessary to raise the question of competence of the international community to distinguish between an act of terrorism and a liberation struggle. The answer partly lies in the complexity of the geopolitical and strategic-tactical objectives that exist in relations between the countries that make up the international community; the complexity of these goals and interests makes the evaluation of committed 
violence rather superficial, selective and incomprehensive, which further slows down the efforts to counteract terrorism.

An inadequate approach to countering terrorism stems from the lack of unequivocal denunciation of terrorism by the international community, which resorts to a less painful method of public condemnation of terrorists and terrorist acts. Thus, the detection of modern forms of terrorism is always belated, whereas the legislation keeps lagging behind even more, which eventually precludes the complete elimination of terrorism as a social phenomenon. The multi-faceted nature of terrorism, as well as its interference with the interests and policies of many countries, including the major super powers, hinders the application of a multidisciplinary approach in examining and counteracting diverse forms of terrorism.

\section{REFERENCES}

Baudrillard, J. (2007). Duh terorizma (The Spirit of Terrorism), Nova srpska politička misao, Beograd, vol. XIV $(1-2)$, str. 211-221.

Dimitrijević, V., (1982). Terorizam (Terrorism), NIRO-Radnička štampa, Beograd, str.37.

Gaćinović, R. (2005). Terorizam (Terrorism), Draslar partner, Beograd.

Gaćinović, R. (2012). Oblici savremenog terorizma (Models of Modern Terrorism), NBP Žurnal za kriminalistiku i pravo, Kriminalističko-policijska akademija, Beograd, 2012(1), str. 1-17).

Horowitz, I. L. (1977). Transnational terrorism, civil liberties and social science. Terrorism: Interdisciplinary perspectives, New York. (pp. 283-297).

Jevtović, Z. (2012). Terorizam i medijski rat (Terrorism and Media War), NBP-Nauka, bezbednost, policija, Kriminalističko-policijska akademija, Beograd, 2012(3), str. 39-63)

Jovašević, D., Rakić M. (2007). Terorizam - bezbednosni pravni aspekti (Terrorism - legal and security aspects), Institut za političke studije, Beograd, str. 59

Konstantinović Vilić, S., Nikolić Ristanović, V., Kostić, M., (2012), Kriminologija (Criminology), Niš: Centar za publikacije Pravnog Fakulteta u Nišu

Memedović, N. (2010). Terorizam - vid ispoljavanja jučerašnje i savremene ljudske destruktivnosti (Terrorisma past and contemporary form of human destructiveness), Pravni život, 539 (9), Beograd (str. 95-101).

Mijalković, S. (2008). Dihotomija organizovanog kriminala i terorizma iz ugla nacionalne bezbednosti (Dichotomy of organized crime and terrorism from the aspect of national security), Revija za bezbednost br. 12, Beograd, (p 39-45)

Milašinović, R., Mijalković, S. (2011). Terorizam kao savremena bezbedonosna pretnja. (Terrorism as a contemporary security threat), Suprotstavljanje terorizmu - međunarodni standardi i pravna regulative, Kozara. (str. 1-16)

Pape, Robert A. (2003). The Strategic Logic of Suicide Terrorism, In: American Political Science Review, vol. 97 (3), pp. 343-361.

Simeunović, D., (2005). Problem definisanja savremenog terorizma (The problem of defining modern terrorism), Srpska politička misao, br. 3-4, Institut za političke studije, Beograd.

Simeunović, D. (2009). Terorizam (Terrorism), Edicija Krimen, Pravni fakultet, Beograd

Šikman, M., (2007). Samoubilački terorizam - fenomenološki i viktimološki aspekti (Suicidal Terrorism phenomenological and victimological aspects), Nauka, bezbednost, policija, vol. 13 (1), Beograd (str. 173-192).

Whittaker, D.J. (2002). Terrorism, understanding the global threat, Pearson Education Limited, Great Britain ( $p$ 128-133).

Cyber Terrorism, Wikipedia - the free encyclopedia, available at: http://sr.wikipedia.org/sr-ec/Sajber_terorizam, $(09 / 13 / 2016)$. 


\section{FENOMENOLOŠKE KARAKTERISTIKE TERORIZMA KAO TEŠKOG OBLIKA POLITIČKOG KRIMINALITETA}

Terorizam kao težak oblik kriminaliteta nasilja, poslednjih decenija, je izrastao u jedan od najvećih $i$ skoro nerešivih izazova kako za državu tako i za međunarodnu zajednicu. Autor je pokušao da doprinese sveobuhvatnom naučnom objašnjenju terorizma kao teškog oblika kriminaliteta nasilja i njegovih fenomenoloških obeležja. Pored toga, autor je pokušao da ukaže da se pronalaženjem i spoznajom metoda, sadržaja, pojavnih oblika i fenomenoloških obeležja terorizma, ide korak napred ka kreiranju uslova za uspešno suprotstavljanje ovom obliku kriminaliteta nasilja. Izučavanje terorizma i njegovih fenomenoloških obeležja je značajno jer se time postiže konsenzus oko oblika ispoljavanja i njegovih glavnih karakteristika, koji će, uz rezultate istraživanja terorizma sa ideološkog, filozofskog, etičkog $i$ drugih aspekata, stvoriti zdravu osnovu za uspešno suprotstavljanje terorističkim aktivnostima.

Ključne reči: terorizam, političko nasilje, bezbednost, izazivanje straha

Proofreading and translation: Gordana Ignjatović 